\title{
AN ANALYSIS OF THE PROPOSAL TO "ABOLISH" THE INSANITY DEFENSE IN S. 1: SQUEEZING A LEMON
}

\author{
Heathcote W. Wales $\dagger$
}

\section{INTRODUCTION}

As debate over the function and administration of the insanity defense has heightened in recent years, abolition of the defense has become an increasingly serious alternative. ${ }^{1}$ The Senate Committee on the Judiciary is now considering one such proposal. Section 522 of the proposed Criminal Justice Reform Act of $1975,{ }^{2}$ popularly known as S. 1 , states a viable defense if "the defendant, as a result of mental disease or defect, lacked the state of mind required as an element of the offense charged. Mental disease or defect does not otherwise constitute a defense."

Born of frustrations over the administration of the insanity

† Associate Professor of Law, Georgetown University, A.B. 1965, University of North Carolina; J.D. 1968, University of Chicago.

1 For the abolitionist positions, see, e.g., S. Halleck, Psychiatry and the Dilemmas of Crime 212-28, 341-42 (1967); H.L.A. Hart, The Morality of the Criminal Law $24-25$ (1964); T. Szasz, Law, Liberty, and Psychiatry 123-46 (1963); B. Wootron, Crime and the Criminal Law (1963); Goldstein, The Brawner Rule-Why? or No More Nonsense on Non Sense in the Criminal Law, Please!, 1973 WasH. U.L.Q. 126; Goldstein \& Katz, Abolish the "Insanity Defense"-Why Not?, 72 YALE L.J. 853 (1963); Morris, Psychiatry and the Dangerous Criminal, 41 So. CAL. L. Rev. 514 (1968). Dean Morris' article contains a summarization of the various positions in an appendix. Id. 544-47.

For arguments that the insanity defense be retained, see, e.g., H. Fingaretre, The Meaning of Criminal Insanity 1-15 (1972); A. Goldstein, The Insanity Defense 222-26 (1967); H. Packer, The Limits of the Criminal Sanction 131-35 (1968); Brady, Abolish the Insanity Defense? -No!, 8 Houston L. Rev. 629 (1971); Kadish, The Decline of Innocence, 26 CAMB. L.J. 273 (1968); Monahan, Abolish the Insanity Defense? -Not Yet, 26 RUTGERS L. REv. 719 (1973).

Platt, The Proposal to Abolish the Federal Insanity Defense: A Critique, 10 CaL. Western L. Rev. 449 (1974), discusses constitutional objections to the Nixon Administration's abolition proposals, but does not consider the manner in which judicial construction can undercut abolition through an expanded version of mens rea. See text accompanying notes 100-31 infra.

${ }^{2}$ S. 1, 94th Cong., 1st Sess. (1975). All citations to S. 1 in this Article refer to the Committee Print of May 16, 1975. 
defense, the death of the Durham experiment, ${ }^{3}$ and the rising influence of the behaviorist position, ${ }^{4}$ the abolitionist argument has become respectable for liberal and conservative alike. A forerunner to section 522 was proposed by a consultant to the National Commission on Reform of Federal Criminal Laws (Brown Commission) in 1970 but was rejected by the Commission..$^{5}$ Abolition of the insanity defense reemerged in the Nixon Administration bill in $1973^{6}$ and has remained in the Judiciary Committee's bill ever since.

Section 522 is abolitionist in the sense of eliminating a "separate insanity defense." Although evidence of mental disease or defect is admissible if it tends to negate the mental ele-

${ }^{3}$ See United States v. Brawner, 471 F.2d 969 (D.C. Cir. 1972) (en banc), overruling Durham v. United States, 214 F.2d 862 (D.C. Cir. 1954).

The Durham experiment was itself born of frustrations over what Judge Bazelon and his colleagues on the District of Columbia Circuit considered the limited scope of expert psychiatric testimony under the M'Naghten rule, M'Naghten's Case, 8 Eng. Rep. 718 (H.L. 1843). See Durham, supra at 866-74. Largely indigenous to the District of Columbia Circuit (New Hampshire has followed a similar rule for nearly a century, see, e.g., State v. Pike, 49 N.H. 399 (1870)), Durham exculpated from criminal punishment those individuals whose forbidden acts were "the product of a mental disease or defect." Durham, supra at 874-75. The standard underwent great flux before its demise. See Carter v. United States, 252 F.2d 608 (D.C. Cir. 1957) (requiring "but for" causation); Blocker v. United States, 274 F.2d 572 (D.C. Cir. 1959) (per curiam) (requiring updated expert testimony on whether a sociopathic personality disturbance is to be considered a mental disease or defect); McDonald v. United States, 312 F.2d 847 (D.C. Cir. 1962) (en banc) (defining mental disease or defect); Washington v. United States, 390 F.2d 444 (D.C. Cir. 1967) (criticizing conclusory psychiatric labels). Finally, in Brawner, the District of Columbia Circuit-with Judge Bazelon concurring in part and dissenting in part, Brawner, supra at 1010-39-rejected the Durham rule, citing as its chief defect the domination of the trier of fact by expert medical and psychiatric witnesses on the issue of insanity, id. at 977-78. The court adopted a modified version of the American Law Institute rule. Compare id. at 990-94, 1006 n.82, 1008, with Model Penal Code \& 401 (Proposed Official Draft 1962).

Though now abandoned and largely unsuccessful in accomplishing its stated goals, Durham at least proved fruitful in stimulating scholarly and judicial debate on the nature and purposes of the insanity defense. See Brawner, supra at 976.

${ }^{4}$ See, e.g., B. Wootron, supra note 1; Monahan, supra note 1, at 733-38.

The behavicrist position stresses that free will is an illusion and that behavior is conditioned by numerous forces, so that the sole function of the criminal law should be to modify the personalities of those committing antisocial acts. Accordingly, insanity becomes relevant only at the sentencing-dispositional stage. See H. PACKER, supra note 1, at 12 .

s See 1 Working Papers of the National Comm'n on Reform of Federal Criminal Laws 234 (1970) [hereinafter cited as WORKIng PaPERs].

${ }^{6}$ S. 1400 , 93d Cong., 1st Sess. $§ 502$ (1973): "It is a defense to a prosecution under any federal criminal statute that the defendant, as a result of mental disease or defect, lacked the state of mind required as an element of the offense charged. Mental disease or defect does not otherwise constitute a defense."

${ }^{7}$ See Staff of Senate Comm. on the Judiciary, 93d Cong., 2d Sess., Report on Criminal Justice Codification, Revision, and Reform Act of 1974, at $111 \mathrm{n} .73$ (Comm. Print 1974) [hereinafter cited as Judiciary Comm. Staff Report]. 
ment (mens rea) of a crime, it does not constitute a general defense of excuse. Proponents are fond of the illustration of the man who strangles his wife believing he is merely squeezing lemons. ${ }^{8}$ His defense is that he lacked the intent to kill another human being. His need for introducing evidence of mental disease would be to give credibility to his story. ${ }^{9}$ If section 522 is indeed restricted to such delusional mistakes of fact, then the draftsmen have succeeded in largely abolishing the insanity defense as we now know it.

Two problems are posed. First, one may question whether such alteration of the insanity defense can coexist with an otherwise rather traditional structure of criminal liability and defenses without standing the logic of that structure on its head. This question poses corollary issues of policy and constitutional interpretation. ${ }^{10}$ Second, one may question whether judicial construction of this "decidely opaque" 11 provision will conform to the expectations of the draftsmen. Distinguished students of the insanity defense have inferred a remarkably broad range of interpretations of the meaning and effect of section $522 .{ }^{12}$

${ }^{8} I d$. 106. The illustration is drawn from Model PeNal Code $\S 4.01$, Comment 2 (Tent. Draft No. 4, 1955).

${ }^{9}$ Given the redundancy between $\S \S 522$ and 521 (mistake of fact or law), see notes 101-10 infra \& accompanying text, it is unclear whether the trier of fact must find that the defendant had a mental disease or defect as a precondition to allowing a defense in the lemon-squeezing illustration. Section 522 implies that such a finding of fact is necessary, as does $\$ 3617$ (c)(4)(B), which requires the expert witness' conclusion on that issue. Yet the defendant's proof would be simplified if he could bring his defense under $\$ 521$; and, if successful, he could win outright acquittal rather than the special verdict of acquittal by reason of insanity with its accompanying civil commitment procedures under $\$ \$ 3612-13$. See note 31 infra.

${ }^{10}$ See text accompanying notes 13-99 infra. The due process clause may well be offended by either partial or total abolition, text accompanying notes 84-99 infra.

${ }^{11}$ Hearings on S. I Before the Subcomm. on Criminal Laws and Procedures of the Senate Comm. on the Judiciary, 94th Cong., 1st Sess., pt. XII, at 219 (1975) (statement of Chief Judge David L. Bazelon, Jr.) [hereinafter cited as 1975 Hearings].

12 While there is a very vague intent to restrict the insanity defense, the use of the terms "mental disease or defect" ambiguously indicates some form of Durham-like experimentation. ... [T] $]$ he Section could be read as endorsing either the view of the court in Brawner on the role of the jury or the view expressed in my dissenting opinion.

Id. 288 (statement of Chief Judge David L. Bazelon, Jr.).

"The ... approach is strikingly reminiscent of the Durham rule." Hearings on $S .1 \&$ S. 1400 Before the Subcomm. on Criminal Laws and Procedures of the Senate Comm. on the Judiciary, 93d Cong., 1st Sess., pt. VIII, at 6381 (1973) (statement of Prof. Abraham S. Goldstein) [hereinafter cited as 1973 Hearings].

"In effect, S. 1 abolishes the defense of insanity, since lack of the required criminal intent is a defense, independent of insanity, in any case." Schwartz, A Proposal to Overhaul the Federal Criminal Laws, N.Y. Times, June 22, 1975, §4 (Week in Review), at 4, col. 5. 


\section{The Lemon Squeezing View}

If we take the draftsmen at their word, section 522 would exculpate mistakes of fact arising from grossly abnormal ideation and little else. ${ }^{13}$ The lemon-squeezing spouse-killer would be acquitted if the jury were persuaded that he literally thought that his wife was a lemon. ${ }^{14}$ But if the same defendant was spurred to kill by voices, by a prolonged depression, or by an uncontrollable rage associated with a tumor or other organic damage, he should be convicted..$^{15}$ Not only would the defense discriminate against particular types of disorders-particularly the affective disorders such as manic-depressive psychosis-but it would also discriminate among phases of delusions arising from a single thought disorder. Thus our lemon-fixated defendant who dispatches his wife while trying to grip her firmly to prevent her turning into a lemon is guilty of reckless homicide. ${ }^{16}$

Beneath this interpretation of section 522 lies the criminal law's traditional objective view of mens rea. The defendant is assumed to be a rational being exercising free choice. ${ }^{17}$ Gradations of culpability are geared to the actor's awareness of his conduct, the circumstances in which he acts, and the consequences of his conduct, as well as to an evaluation of the objective conduct, circumstances, and consequences themselves. ${ }^{18}$

${ }^{13}$ See Judiciary Comm. Staff Report, supra note 7 , at 106. Similarly, if $A$ suffers from paranoid delusions that $B$ is trying to kill him, and $A$ kills $B, A$ would be entitled to an imperfect defense of self-defense, reducing his crime to reckless or negligent homicide. See S. 1, 94th Cong., 1st Sess. § 544(b) (1975).

${ }^{14}$ Actually he could be convicted of negligent homicide, S. 1, 94th Cong., Ist Sess. § 1603 (1975), unless the subjective aspect of negligence-"a reasonable person . . . in such a situation," $i d$. \$302-were enlarged to include his mental abnormality. See Kadish, supra note 1 , at 280 .

15 See Judiciary Comm. Staff Report, supra note 7, at 107 n.64.

${ }^{16}$ A similar case occurred recently in Washington, D. C. Defendant, waiting at a bus stop, perceived that a woman stranger standing near him was rapidly changing shapes. He proceeded to throttle her-as he explained it, to make her stay in one form so that he could talk to her. The woman was near death when the man was pulled away by onlookers. The police, rather than booking him, delivered him to St. Elizabeth's Hospital for reasons of convenience to the police, and the man was civilly committed. No criminal charges were filed. Conversation between Herbert M. Silverberg, Chief, Mental Health Division, Public Defender Service, St. Elizabeth's Hospital, Washington, D.C., and the author, Dec. 3, 1974.

17 "Historically, our substantive criminal law is based upon a theory of punishing the vicious will. It postulates a free agent confronted with a choice between doing right and doing wrong and choosing freely to do wrong." Morissette v. United States, 342 U.S. 246, 250 n.4 (1952), (quoting Pound, Introduction to F. SAYre, Cases on Criminal Law xxxvi-xxxvii (1927)). See also Durham v. United States, 214 F.2d 862, 876 (D.C. Cir. 1954). 4 W. BLACKSTONE, COMMENTARIES *20-21.

18 "If a man intentionally adopts certain conduct in certain circumstances known to 
Therefore, the only way to negate mens rea, strictly speaking, is to demonstrate the absence of awareness of the conduct, circumstances, or consequences to which the mens rea applies. In so doing, one never reaches the underlying assumption that the defendant is a rational being.

Mens rea has not always been so narrow a construct. ${ }^{19}$ Terms such as "malice," "premeditation," and "deliberation" have from time to time incorporated into the criminal law qualitative concepts of culpability beyond mere awareness of conduct, circumstances, and consequences. Recent codification efforts, however, including sections 301 and 302 of S. 1, have followed the lead of the Model Penal Code in refining a more objective concept of mens rea. ${ }^{20}$ Thus, the lemon-squeezing view of section 522 is consistent with the emerging view of mens rea.

But what of the underlying assumption of free will? The Model Penal Code and virtually every code derived from it provide at least two defenses unrelated to mens rea that may negate the threshold capacity for free choice assumed by the criminal law. One, the automatism or involuntariness defense, negates a prescribed element of the crime, the requirement of a voluntary act or omission. ${ }^{21}$ The other, the insanity defense, assumes a voluntary or conscious act and is directed at substantial impairments to the capacity for free choice arising from mental disorder. ${ }^{22}$ Together, the two defenses suggest a concept of culpability broader than that reflected by the element of mens rea. ${ }^{23}$ It is only when the two-step hurdle of minimal capacity for free choice has been crossed-whether by presumption or by the state's overcoming defense evidence-that the more refined measures of culpability contained in the mens rea element are brought into play. Yet neither defense exists on the face of S. $1 .^{24}$

him, and that conduct is forbidden by law under those circumstances, he intentionally breaks the law in the only sense in which the law ever considers intent." Ellis v. United States, 206 U.S. 246, 257 (1907). (1936).

${ }^{19}$ See generally Turner, The Mental Element in Crimes at Common Law, 6 Cамв. L.J. 31

${ }^{20}$ Model Penal, Code $\$ 2.02$ (Proposed Official Draft 1962).

${ }^{21}$ See, e.g., Model Penal Code $\S 2.01$ (1) (Proposed Official Draft 1962). See generally

W. LaFave \& A. Scott, Criminal Law 179-81 (1972).

${ }^{22}$ See, e.g., Model Penal Code $\$ 4.01$ (Proposed Official Draft 1962).

${ }^{23}$ Other defenses, such as duress, self-defense, and provocation, also tend to reflect a broader, more subjective notion of culpability. See generally notes 111-13 infra \& accompanying text.

${ }^{24}$ See S. 1, 94th Cong., 1st Sess. \$§ 102, 111 (1975). But see id. § 501 (defenses listed in $S . I$ are not exclusive). 


\section{A. The Committee's Rationale}

The Senate Judiciary Committee's Staff Report ${ }^{25}$ does not directly confront the significant changes in the culpability concept implied in the lemon-squeezing interpretation of section 522. Rather, the Report criticizes current formulations of the insanity defense as vague, wasteful, and inefficient and urges simple abolition of the inquiry into concepts of responsibility in favor of more efficient procedures for sorting out and designating for treatment those offenders exhibiting psychopathology of any variety. "The critical issue is seen as one of disposition." 27 Indeed, the Report advances the novel argument ${ }^{28}$ that dispositional proceedings constitute a proper forum for determining culpability.

[T] he stigma attached to a determination of criminality will be materially mitigated at the sentencing stage by publicly adjudging [persons convicted under S. 1 who would have been acquitted under other insanity tests] to be deserving of proper medical care rather than deserving of a punitive sentence of imprisonment. The nature of the disposition ... will constitute society's recognition of the defendant's lack of moral culpability for his offense. $^{29}$

Dean Morris has argued that the current practice of delivering a special verdict of acquittal by reason of insanity combined with the commitment of insanity acquittees amounts to double stigmatization of the defendant as both bad and mad. ${ }^{30}$ Surely a criminal conviction combined with commitment to a psychiatric facility for criminals will not ameliorate the stigma visited upon this unfortunate class. ${ }^{31}$ Furthermore, hospitalization of a con-

${ }^{25}$ JUdiciary Comm. STAFF RePort, supra note 7.

${ }^{26}$ These procedures can be found in S. 1, 94th Cong., Ist Sess. \$§ 3611-17 (1975).

${ }^{27}$ Judiciary Comm. STAFF RePort, supra note 7 , at 106.

${ }^{28} S_{e e}$ B. Wootron, supra note 1 . In contrast to the Woottonian position, which attempts to eliminate all elements of culpability, the S. 1 abolitionist approach would apparently retain culpability while allowing psychiatric evidence at the dispositional hearing of an offender convicted because he was unable to establish a mistake-of-fact defense based on mental disease or defect.

${ }^{29}$ Judiciary Comm. Staff Report, supra note 7, at 107.

30 Morris, supra note 1 , at 524-25.

${ }^{31}$ See Kadish, supra note 1, at 283; Monahan, supra note 1, at 729-31. For those few who may be acquitted under $\S 522$, the same, less formal double stigmatization occurs. Defendants are accorded a "special verdict" of "not guilty by reason of insanity" under $\S$ 3612 and are subjected to proceedings under $\$ 3613$ to determine whether they should be indefinitely hospitalized as mentally ill and dangerous. 
victed person under S. 1 occurs when the person is found to be suffering from a mental disease or defect and in need of treatment, ${ }^{32}$ so that persons who might have been acquitted under other insanity tests will be grouped with all other prisoners who might benefit from psychiatric care, whether or not their mental disabilities contributed to their criminal conduct. Finally, disposition occurs without a jury ${ }^{33}$ and in substantial reliance on a psychiatrist's opinion as to the prisoner's present mental condition. Culpability is simply not in issue.

On a practical level, substituting criminal sentences with medical treatment for the idefinite commitments usually given to persons acquitted under current insanity tests is no favor to the accused, despite the Committee's suggestion to the contrary. ${ }^{34}$ Maximum sentences under S. 1 are already substantial, and section 3616 permits indefinite commitment of prisoners whose sentences have expired but who are found to be mentally ill and dangerous. A convicted person is compelled to receive psychiatric treatment under sections 3614 and 3615 until he is no longer in need of treatment, whereas section 3613 requires treatment of the insanity acquittee only so long as he is mentally ill and dangerous. When the prisoner is discharged from treatment, he may have to return to prison for the remainder of his sentence, ${ }^{35}$ a factor that may discourage discharge. ${ }^{36}$ In short, convicting those who might otherwise win insanity acquittals subjects such

${ }^{32}$ S. 1, 94th Cong., lst Sess. $\S \S 3614(d), 3615$ (d) (1975). Because of its extreme breadth and flexibility, the standard "in need of treatment" raises serious policy and constitutional questions. Some psychiatrists would view almost any prisoner to be in need of treatment. See, e.g., Menninger, Medicolegal Proposals of the American Psychiatric Association, 19 J. CRIM. L.C. \& P.S. 367, 373 (1928). For the argument that "commitment on these grounds [mentally ill or in need of treatment] is of necessity a completely arbitrary act," see Ennis \& Litwack, Psychiatry and the Presumption of Expertise: Flipping Coins in the Courtroom, 62 CALIF. L. Rev. 693, 748 (1974). See also Developments in the Law-Civil Commitment of the Mentally Ill, 87 Harv. L. Rev. 1190, 1212-19 (1974).

${ }^{33}$ S. 1, 94th Cong., 1st Sess. \$\$ 3614(d), 3615(d) (1975); see 1973 Hearings, supra note 11, at 6379; Gray, The Insanity Defense: Historical Development and Contemporary Relevance, 10 AM. Crim. L. Rev. 559, 583 n.103 (1972).

34 JUdiciary Comm. StafF Report, supra note 7, at 108-09.

35 Persons committed while they are serving prison sentences, S. 1, 94th Cong., 2d Sess. $\S 3615$ (1975), must be returned to prison for the remainder of their sentences upon discharge from the hospital, id. $\$ 3615$ (e). However, persons committed after conviction but prior to sentencing, id. $\S 3614$, may, upon discharge from the hospital, obtain adjustment of sentence, id. $\S 3614$ (e). The tradeoff is that $\S 3614$ commitments are given provisional maximum sentences for their offenses at the time of commitment, id. $\S 3614$ (d).

${ }^{36}$ Some psychiatrists may be reluctant to return patients to prison for fear that the prison environment will occasion a relapse. Should this occur in the context of $\S 3614$ commitments, persons so committed would in effect be receiving automatic maximum 
persons to incarceration for a period determined by their past criminal conduct as well as by their future propensities, whereas commitment of insanity acquittees, in theory at least, relates only to future dangerousness. ${ }^{37}$

Nor can we take comfort in the Committee's second justification for criminalizing the class that under current insanity tests would be acquitted. In one breath, the Committee suggests that the injustice wrought by extending culpability to this class will be minimal because the class is so small. ${ }^{38}$ In the next breath, the Committee urges the benefits to the criminal justice system of convicting members of this meager class who should and would have been convicted but for the vagaries of existing insanity formulations. ${ }^{39}$ Playing the numbers both ways is awkward enough; suggesting that it is better to convict ten nonculpable persons than to let one malingerer go free is strange talk indeed. ${ }^{40}$

The remaining justifications advanced by the Committee for narrowing the insanity defense form a catalog of the criticisms directed at existing insanity tests. With one exception, all of these criticisms are equally applicable to section 522 . Like other formulations, the section 522 defense is subject to expert domination, both because it is tied to a factual finding of "mental disease or defect" ${ }^{41}$ and because psychiatric experts are required by section

sentences solely because they were found mentally ill and in need of hospitalization. See note 35 supra.

Furthermore, insanity acquittees committed under $\S 3613$ are likely to be deemed by the courts to be entitled to the least restrictive form of confinement and/or treatment consistent with their mental condition and degree of dangerousness. See generally Covington v. Harris, 419 F.2d 617 (D.C. Cir. 1969); Chambers, Alternatives to Civil Commitment of the Mentally Ill: Practical Guides and Constitutional Imperatives, $70 \mathrm{MrcH}$. L. REv. 1107 (1972). The application of the least restrictive alternative doctrine will of necessity be more restrictive for those committed while awaiting or serving criminal sentences under $\$ 3614-15$.

${ }^{37}$ To the extent that theory does not conform to practice, see note 49 infra, the better approach would seem to be to reform the practice rather than to adulterate the theory.

${ }^{38}$ Judiciary Comm. STAfF Report, supra note 7, at 107 n.63.

${ }^{39}$ Id. But cf. State v. Strasburg, 60 Wash. 106, 131, 110 P. 1020, 1028 (1910) (Rudkin, C.J., concurring): "[T] $]$ he remedy for acquittals through maudlin sentiment or in response to popular clamor must be sought by correcting false notions, and not by destroying the safeguards of private liberty."

${ }^{40}$ Even if we can agree on who "should" have been acquitted by reason of insanity, it is unlikely that the number of persons "improperly" acquitted is very large. Most persons who might qualify for the defense never go to trial on the issue. See A. Goldstern, supra note 1, at 23-24; Morris, supra note 1, at 519.

${ }^{41}$ See note 9 supra. See also Washington v. United States, 390 F.2d 444 (D.C. Cir. 1967); 1975 Hearings, supra note 11, at 225 (statement of Chief Judge David L. Bazelon, Jr.). 
3617 (c)(4)(B) to give conclusory testimony on whether the mental disease or defect operated to negate the defendant's mens rea at the time of the offense. ${ }^{42}$ Like other formulations, section 522 is likely to remain a "rich man's defense" 43 because section 3617(b) denies the indigent accused the right to an independent psychiatrist. Like M'Naghten, ${ }^{44}$ section 522 emphasizes cognitive mental functioning to the exclusion of all else. Like other formulations, section 522 mingles vague medical terms (mental disease or defect) unintelligible to lawyers with an unrelated moral-legal term (mens rea). ${ }^{45}$ Like many existing procedural provisions, section 3613 insures that those few persons who are acquitted under section 522 will be hospitalized indefinitely if found to be mentally ill and dangerous. ${ }^{46}$

The one criticism of existing insanity tests that section 522 does attempt to resolve is that psychiatric resources have been misallocated to the guilt-determination process when they could be devoted to treatment. If the courts adopt the strict lemonsqueezing view of section 522, a contingency that is questioned below, ${ }^{47}$ then the number of defendants raising the insanity defense will probably drop, thereby reducing the allocation of psychiatric resources to determinations of guilt. ${ }^{48}$ The possibility that such gains may be offset by other demands on psyshiatric resources by other provisions of $S .1$ is not considered in the Committee Staff's Report. ${ }^{49}$

42 If the courts respond to $\S 522$ 's limitation on the insanity defense, as $I$ believe they will, by articulating a broader mens rea defense, see text accompanying notes 100-31 infra, expert conclusions will continue to dominate the adjudication stage.

43 Judiciary Comm. Stafe Report, supra note 7, at 108 n.65.

${ }_{44}$ M'Naghten's Case, 8 Eng. Rep. 718 (H.L. 1843).

45 The Report confesses this defect but notes that "the reduction in availability of the defense reduces the harm and impact of the necessary vagueness." Judiciary Comm. StafF RePoRT, supra note 7, at 110 . That statement may be applicable to other defects in $\S 552$ as well.

${ }^{46}$ Even in jurisdictions that do not make commitment of insanity acquittees automatic, in practice commitment ensues in virtually every case. See Pugh, The Insanity Defense in Operation: A Practicing Psychiatrist Views Durham and Brawner, 1973 Wash. U.L.Q. 87, 92 n.8. See also Goldstein, supra note 1 at 132-33.

${ }^{47}$ See notes 100-31 infra and accompanying text.

${ }^{48}$ See Judiciary Comm. Staff Report, supra note 7, at 111.

${ }^{49}$ For example, hearings required by $\$ \S 3614-15$ for hospitalization of persons who under other insanity tests might have been acquitted will require some psychiatric participation in an adversary setting. Similarly, persons committed under these sections may be hospitalized for longer periods than if they had been civilly committed. $C f$. Burt, of Mad Dogs and Scientists: The Perils of the "Criminal-Insane," 123 U. PA. L. Rev. 258, 261 (1974): "The systematic empirical research available in current literature has uniformly found that those persons caught in the 'criminal-insane' statuses are as a rule confined 
The policy of getting psychiatrists out of the courtroom has multiple objectives, ${ }^{50}$ not all of them commendable. To the extent that the draftsmen wish to end "the unseemly battle of the experts," ${ }^{1}$ their solution seems misdirected. The battle becomes unseemly only when the experts stray beyond their expertise into opinions on law and morality, whether such wanderings are the result of their own foibles or the law's specific requests. ${ }^{\mathbf{5 2}}$ Legislators might more profitably direct their efforts toward limiting the experts to testimony on their clinical assessments of a defendant's mental functioning at the time of the alleged offense. ${ }^{53}$ Presumably, public disagreement between two psychiatrists over such clinical judgments does not diminish their stature or that of their profession.

Thus the Senate draftsmen address deficiencies in the operation of current insanity defense formulations by reducing the availability (and visibility) of the defense rather than by attempting to cure the deficiences. ${ }^{54}$ The draftsmen seem to perceive the defense as having failed as a mechanism for diversion of the sick offender to non-punitive treatment, a point already conceded by others on both practical ${ }^{55}$ and constitutional ${ }^{56}$ grounds. Hence, the primary drafting efforts in S. 1 for mentally abnormal offenders have been directed toward tightening up disposition procedures to insure such offenders' detention until they are no longer dangerous. ${ }^{57}$ What is missing is an effort to recon-

for longer terms than comparable persons who are socially labeled either 'criminal' or 'insane' alone." See also text accompanying note 37 supra.

so See Judiciary Comm. Staff RePort, supra note 7, at 111.

${ }^{51} \mathrm{Id}$.

${ }^{52}$ See Wales, The Rise, the Fall, and the Resurrection of the Medical Model, 63 GEo. L.J. 87, 91-93 (1974). Compare Psychiatric News, Feb. 5, 1974, at 23, col. 1 (Dr. Alan Stone, urging psychiatrists to stay out of the courtroom) with Bazelon, Psychiatrists and the Adversary Process, Scientific Am., June 1974, at 18.

${ }^{53}$ Section $3617(c)(4)(B)$ takes directly the opposite approach, requiring psychiatrists to report in conclusory terms whether the defendant's mental disease or defect negated the mental elements in the crimes charged.

54 See note 45 supra.

${ }^{55}$ See A. Goldstein, supra note 1 , at 219.

${ }^{56}$ See Bolton v. Harris, 395 F.2d 642 (D.C. Cir. 1968) (Bazelon, J.) (interpreting D.C. CODE ANN. \$24-301(a), (d) (1967) to require pre-commitment hearing for insanity acquittees with procedures substantially similar to those in civil commitment proceedings, avoiding equal protection issue). See generally Note, Commitment of Persons Acquitted by Reason of Insanity: The Example of the District of Columbia, 74 Colum. L. REv. 733 (1974); Comment, Commitment Following Acquittal by Reason of Insanity and the Equal Protection of the Laws, 116 U. PA. L. Rev. 924 (1968).

${ }^{57}$ See S. 1, 94th Cong., 1st Sess. $\$ \$ 3611-17$ (1975); Judiciary Comm. Staff Report, supra note 7 , at $1000-18$. 
cile the changes wrought by section 522 with the criminal law's concept of culpability and fully to rationalize the preventive confinement scheme created by the new dispositional provisions.

\section{B. Abolition-A Second Look}

Dean Morris, whose stylish article may well have been the basis for the lemon-squeezing version of section $522,{ }^{58}$ addresses the culpability issue somewhat more fully than the Senate draftsmen, although he too is primarily concerned with removing psychiatrists from the courtroom to the correctional process. In so doing, he passes over the impact of his proposal on the emerging jurisprudence of preventive confinement.

Dean Morris begins by suggesting that current formulations of the insanity defense are too narrow. By conditioning the defense on a finding of mental disease or defect, the law ignores other equally potent impairments to the exercise of free will, such as "dwelling in a Negro ghetto." 59 If we are unwilling to recognize a broader defense of incapacity, a solution which, he argues, "would politically be intolerable,"60 then we do no great injustice to eliminate the excuse based on mental illness. ${ }^{61}$

But what is meant by "politically ... intolerable?" Dean Morris seems to suggest that because dwelling in a black ghetto is more criminogenic than being mentally ill, the former is a more

${ }^{58}$ Morris, supra note 1 . It is unlikely, however, that Dean Morris would support the dispositional provisions of $\$ \$ 3611-17$. Id. 529-36.

${ }^{59}$ Id. 520.

${ }^{\text {Bo } I d .}$.

61 This argument is bolstered by (1) the trend toward elimination of capital punishment, (2) the low incidence of the insanity defense, and (3) the problem of informal double stigmatization. Id. 518-19, 524-25. See note 31 supra.

The premise of point (2) above, incidentally, is highly doubtful. While it is true that the insanity defense itself is none too often invoked, it may well be that many accused who might otherwise have availed themselves of the defense are instead diverted to treatment facilities before reaching a full trial. One such diversion method is the competency hearing; formerly, if at such a hearing the accused was found incompetent to stand trial, under most statutes he was confined for such indeterminate period as it might take him to gain competency. See Burt \& Morris, $A$ Proposal for the Abolition of the Incompetency Plea, 40 U. CHI. L. Rev. 66, 66-67 n.4 (1972). But see Jackson v. Indiana, 406 U.S. 715 (1972) (Blackmun, J.) (incompetency commitment cannot exceed "reasonable" period of time necessary to determine whether there is a substantial chance of defendant's attaining capacity to stand trial in the foreseeable future. Thus prosecutors may be pressed to negotiate pleas through, say, a finding of incompetency to stand trial, see A. Brooks, Law, Psychiatry and the Mental Health System 332 (1974), but such pressure might well be reduced if the breadth of the insanity defense were narrowed by $\mathrm{S}$. 1 .

For a discussion of the abuse of competency hearings, see Ennis, C.L.U. Client "Crazy but Competent," reprinted in A. BRooks, supra at 334-37. 
compelling defense than the latter. ${ }^{62}$ But being mentally healthy may also be more criminogenic than being mentally ill. ${ }^{63}$ The issue is not what condition is most criminogenic but what condition so deprives an individual of the capacity for free choice that he cannot be held responsible for his conduct. And just as juries now convict in all but the most extreme cases of mental abnormality, one might expect a similar pattern should "dwelling in a Negro ghetto" become admissible evidence on the issue of criminal responsibility. ${ }^{64}$ Nor would such a pattern suggest moral inconsistency in the law. ${ }^{65}$ Our only inconsistency is in failing to allow the jury to hear all evidence relevant to a defendant's capacity for free choice. For it is the jury, not legal scholars, who are best situated and best equipped, assuming access to relevant evidence, to determine moral guilt. ${ }^{66}$

But having dismissed one aspect of criminal responsibility ${ }^{67}$ for its underinclusiveness, Dean Morris then argues for the retention of the aspect of moral responsibility borne by the objective version of mens rea. Accidental (non-negligent) criminal conduct and the delusional mistake of fact will continue to excuse whereas the offender who accurately perceives what he is doing but is powerless to exercise moral judgment will suffer conviction, imprisonment, and involuntary medical treatment. ${ }^{68}$ In (1974)

${ }^{62}$ Morris, supra note 1 , at 520.

${ }^{63}$ See Diamond, The Psychiatric Prediction of Dangerousness, 123 U.PA. L. REv. 439

${ }^{64}$ One is tempted to speculate how a defense lawyer who intended to raise such a defense might proceed in selecting a jury. My own guess is that upper middle class, educated whites would be preferred over ghetto blacks.

${ }^{65}$ See Kadish, supra note 1, at 284 ("It is never a reason for adding to injustice that we are already guilty of some."); $\mathrm{H}$. PACKER, supra note 1, at 133 ("The point is that our attitudes toward volitional impairment can change, and the criminal law can change with them"); 1973 Hearings, supra note 12, at 6377: "So long as we do not know what really 'causes' crime, the insanity defense will have to be framed in a way which permits juries to express the feelings of the community on the subject of responsibility."

66 "[The insanity defense represents] a normative standard applied to conflicting clusters of fact and opinion by a jury, an institution which is the traditional embodiment of community morality and, therefore, well suited to determining whether a particular defendant, and his act, warrant condemnation rather than compassion." Id. 6377. See also note 136 infra \& accompanying text.

${ }^{67}$ Dean Morris eschews consideration of the defense of automatism or involuntariness in his analysis. See Morris, supra note 1, at 528 n.33. Presumably his argument would extend to abolishing that defense as well.

${ }^{68}$ Under S. 1, 94th Cong., 1st Sess. § 3614 (1975), a convicted person suffering from a mental disease or defect may be involuntarily hospitalized upon motion of the Government after a hearing and an appropriate judicial determination. The insanity acquittee, on the other hand, may be hospitalized only if "his release would create a substantial danger to himself or to the person or property of another." Id. \$ 3613(a). 
short, Dean Morris has rejected Lady Wootton's logical extension of his argument to postpone all considerations of culpability to the disposition proceeding. ${ }^{69}$ But why? For purposes of imposing blame, the conduct of the Hadfields ${ }^{70}$ and M'Naghtens would seem no more opprobrious than that of the lemonsqueezing spouse-killer. For purposes of deterrence, we may achieve greater success in punishing accidental behavior not rising to criminal negligence than we do in punishing violent street crime. ${ }^{71}$ Behavior-modifying treatment is clearly worth considering for the lemon-squeezing spouse-killer and may benefit the accident-prone as well; both types of offenders may pose the danger of future harm. Dean Morris' distinction poses many of the same difficulties as the current insanity defense.

From a larger perspective, Dean Morris sees his proposal for elimination of the insanity defense as a first step on the low road toward elimination of the concept of retribution from criminal law. ${ }^{72}$

There is a choice. We could follow the pattern of gradually extending the exculpatory and allegedly destigmatizing defense of insanity to cover larger and larger slices of criminal conduct, until it encompasses most criminal behavior. Many working in this field favor the engulfing process. I do not oppose their purpose, but I do think their political judgment is wrong. ${ }^{73}$

But Dean Morris' first step is not the most logical, only the most politically acceptable. And it is not clear that those who would "expand" the insanity defense by eliminating the restriction of mental disease or defect are aiming for the same goal. There may yet be utility in perpetuating our constructs of free will and blame in the face of mounting psychological evidence that free

69 B. Wootron, supra note 1.

70 Hadfield's Case, 27 Howell St. Tr. 1282 (K.B. 1800). Hadfield, who had brain damage from a war wound, attempted to assassinate King George III to save the world.

${ }^{1}$ See Zimring \& Hawkins, Deterrence and Negligent Behavior: A Preliminary Note (unpublished manuscript on file with the author), reporting on a 1965 study of keylosing behavior in a midwestern automobile plant and finding such behavior deterrable. See also F. Zimring \& G. Hawkins, Deterrence: The Legal. Threat in Crime Control 128-41 (1973).

${ }^{72}$ See Morris, supra note 1, at 526: "I do not believe that systems of justice can long survive in which name calling and vengeance figure so prominently. If this be so, then the issue we are debating becomes one of how we can destigmatize our criminal law processes as rapidly as possible."

${ }^{73} I d$. 
will is illusory. Empirical evidence abounds for "the proposition that an individual's perception of personal responsibility or free will affects his behavior in important ways."74 Until it can be shown that the insanity defense and related responsibility defenses do not "[reinforce] the average citizen's belief in his own personal responsibility," 75 we may be better off maintaining the criminal law's emphasis on culpability. ${ }^{76}$

Dean Morris himself illustrates our reliance on the principle of blameworthiness, observing that sentencing and parole decisions which reflect judgments of the offender's potential dangerousness are frequently made " $[w]$ ithin the ambit of power defined by other purposes (most of them retributive)."77 Because our ability to predict future dangerousness and to "cure" antisocial propensities is so tenuous, he argues, we should not create state power over a criminal's life on those bases alone. ${ }^{78}$ Yet he has done just that by making the insane offender criminally liable for his conduct: He would defuse retribution as a justification for confinement by abolishing a significant aspect of culpability. Nor would deterrence be greatly advanced by criminalizing the insane. Society's real purposes in confining such offenders, for the most part, would be prevention and treatment.

The key point is that retribution and accompanying notions of blameworthiness constitute a substantial restraint on state power over the individual. ${ }^{79}$ If we are to extend state power over individuals to the substantially blameless in an attempt to eradicate their dangerous propensities, we should do so directly and openly under the rubric of a new jurisprudence of preventive confinement rather than indirectly by warping traditional concepts of criminal accountability. The direct approach would

${ }^{74}$ Monahan, supra note 1 , at 721 .

${ }^{75} \mathrm{Id}$. 723. Professor Monahan postulates two psychological processes, neither of which has empirical support and either of which could occur in response to the law's embracing the insanity defense: (1) the "process of contrast," by which persons "contrast their own "normal' behavior with that of the defendant" and thereby gain an increased sense of their own responsibility, and (2) the process of "assimilation," by which persons might respond to acquittals by questioning their own capacity to control their conduct. $I d$. 724-25.

76 See A. Goldstein, supra note 1, at 223-26; 1973 Hearings, supra note 12, at 6378-79 (statement of Prof. Abraham S. Goldstein). See generally Reich, Reflections, THE NEw Yorker, June 19, 1971, at 52.

${ }^{77}$ Morris, supra note 1 , at 532-33.

${ }^{78}$ Morris, Impediments to Penal Reform, 33 U. CHI. L. REv. 627, 637-44 (1966).

${ }^{79}$ See generally Kadish, supra note 1, at 287-89. 
focus our attention on the real values at issue when the state seeks power to confine and treat those whose propensities we fear.

Most important of the unresolved issues in our jurisprudence of preventive confinement is the problem of proportionality. ${ }^{80}$ Dean Morris' proposal would make confinement proportional with a proven past offense. Yet the primary rationale for such a link lies in retribution and deterrence, policies that are not seriously advanced by convicting the insane. If our real reasons for confinement are primarily preventive, then our theory of proportionality should be fixed on those harms we hope to prevent and on the degree of certainty with which we may anticipate such harms. ${ }^{81}$ Dean Morris' proposal would mask this issue from view. ${ }^{82}$

The dispositional provisions of S. 1 illustrate how Dean Morris' proposal can be misused. In addition to "punishing" the insane for their past conduct, S. 1 would preventively confine the offender until he "has recovered from his mental disease or defect to such an extent that his release would no longer create a substantial danger." ${ }^{33}$ Even if a reviewing court applies notions of proportionality to the latter, more obviously preventive portion of an offender's confinement, it will be shielded from scrutiny of the initial sentence which, though administered largely for preventive reasons, will appear nominally as a term of "punishment" (involving primarily retribution and deterrence)

${ }^{80}$ See Dershowitz, Preventive Confinement: A Suggested Framework for Constitutional Analysis, 51 Texas L. Rev. 1277, 1321-24 (1973). See also Dershowitz, Indeterminate Confinement: Letting the Therapy Fit the Harm, 123 U. PA. L. REv. 297, 328-38 (1974).

${ }^{81}$ A third element might be our capacity to alter the predicted behavior.

82 Professor Dershowitz' historical research has shown us that formal and informal systems of preventive confinement go back to the time of the Normans and seem unlikely to wither away in the imminent future. Dershowitz, The Origins of Preventive Confinement in Anglo-American Law-Part I: The English Experience, 43 U. CIN. L. REv. 1 (1974); Dershowitz, The Origins of Preventive Confinement in Anglo-American Law-Part II: The American Experience, 43 U. CIN. L. REv. 781 (1974). His findings support the hypothesis that as formal criminal conviction becomes more difficult, persons thought to be dangerous but not convictable are shunted to less formal systems of preventive confinement, much as the air in a balloon is squeezed from one end to another. In his terms then, Dean Morris is simply squeezing the preventive confinement end of the balloon and pushing those currently viewed as lacking criminal responsibility back into the criminal justice system. The alternative urged here is that we confront the reality of preventive confinement and develop a jurisprudence to either tame or eliminate it. Whether pursuit of this alternative will cause other air pockets to form-e.g., the expansion of surveillance and intelligence systems-remains to be seen.

${ }^{83}$ S. 1, 94th Cong., 1st Sess. $§ 3616$ (1975). 
for past conduct. The state will have won two periods of preventive confinement for the price of one.

\section{Constitutional Considerations}

Oddly enough, Dean Morris' one-step-at-a-time approach to the destigmatization of the criminal law may be more difficult to square with the constitutional precepts of substantive due process and cruel and unusual punishment than Lady Wootton's more radical proposal of a totally behaviorist approach. For as long as courts view stigmatization as a significant component of criminal conviction, they will impute to the criminal conviction a quantum of blameworthiness greater than that reflected in the objective ${ }^{84}$ version of mens rea. ${ }^{85}$ Efforts to exclude defenses to the larger notion , of culpability will thus be viewed with some suspicion, particularly when such defenses are as deeply imbedded in common law as are insanity and automatism.

That such defenses are so deeply imbedded in the common law may account for the infrequency of legislative attempts to eliminate the insanity defense and the consequent lack of case law on the constitutionality of such efforts. Only two states have seriously attempted to abolish this defense, ${ }^{86}$ while a third attempted to transfer the power to rule on insanity to experts and thus beyond the court's jurisdiction. ${ }^{87}$ Perhaps the best statement of the matter is found in the plurality opinion in State $v$. Strasburg, ${ }^{88}$ wherein the Washington supreme court, on state constitutional grounds, invalidated a statute excluding evidence of insanity from criminal trials. The defendant's sanity at the time of the act charged, ruled three of the justices, is "as much a substantive fact, going to make up his guilt, as the fact of his

\footnotetext{
${ }^{84}$ The "objective" version of mens rea is that version that refuses to find culpability without an erroneous perception of fact.

${ }^{85}$ See generally note 17 supra.

${ }^{86}$ See Sinclair v. United States, 161 Miss. 142, 132 So. 581 (1931) (per curiam) (invalidating Act of Apr. 3, 1928, ch. 75, [1928] Miss. Gen. Laws 92, on state due process grounds, with three of six justices authoring or joining in concurring opinions, 161 Miss. at 154-71, 132 So. at 582-88, attacking statute on federal due process and eighth amendment grounds); State v. Strasburg, 60 Wash. 106, 110 P. 1020 (1910) (invalidating Act of Mar. 22, 1909, ch. 249, § 7, [1909] Wash. Sess. Laws 891, on state due process grounds, with at least three and possibly a majority of justices, 60 Wash. at 110-32, $110 \mathrm{P}$. at 1020-28, finding statute violative of right to jury trial under state constitution). See also Commonwealth v. Vogel, 440 Pa. 1, 268 A.2d 89 (1970).

${ }^{87}$ See State v. Lange, 168 La. 958, 123 So. 639 (1929) (invalidating Act of Dec. 18, 1928, [1928] La. Acts Extra Sess. 34).

${ }^{88} 60$ Wash. 106, 110 P. 1020 (1910).
} 
physical commission of the act." 89 These justices explained:

If he was insane at the time to the extent that he could not comprehend the nature and quality of the act-in other words, if he had no will to control the physical act of his physical body, how can it in truth be said that the act was his act? To take from the accused the opportunity to offer evidence tending to prove this fact, is, in our opinion, as much a violation of his constitutional right of trial by jury as to take from him the right to offer evidence before the jury tending to show that he did not physically commit the act or physically set in motion a train of events resulting in the act. ${ }^{90}$

At first glance, this reasoning suggests that evidence of insanity may be relevant to negate any or all of the three major components of criminal liability - mens rea, actus reus, and causation. ${ }^{91}$ By subsequently suggesting that the insanity defense must be permitted even in crimes of strict liability, ${ }^{92}$ the justices clearly indicated that the defense goes to a concept of culpability broader than mens rea. Thus they may have viewed insanity as going to the defendant's capacity for criminal responsibility-an issue not necessarily raised directly by the elements of mens rea, actus reus, and causation, but one that could not be taken from the jury's ultimate consideration of guilt or innocence.

Although Strasburg was based on the state constitution, its reasoning could be used in a federal constitutional challenge. The factual distinction between the total abolition statute in Strasburg and the near total abolitionary rule of S. 1's section 522 should give little comfort to the Senate draftsmen..$^{93}$ The Washington justices clearly viewed evidence of insanity to be relevant (and therefore constitutionally nonexcludable) to aspects of culpability beyond those reflected in the defense of mistake of fact. Moreover, S. 1's apparent exclusion of an involuntariness defense to the conduct element would render section 522 unconstitutional under the Strasburg reasoning. ${ }^{94}$

${ }^{89}$ Id. at $119,110 \mathrm{P}$. at 1024 .

${ }^{90} \mathrm{Id}$. Although phrased in terms of the right to a jury trial, the justices' argument more closely resembles a substantive due process approach.

${ }^{91}$ Cf. Dix, Psychological Abnormality as a Factor in Grading Criminal Liability: Diminished Capacity, Diminished Responsibility, and the Like, 62 J. CRIM. L.C. \& P.S. 313, 327-28 (1971).

9260 Wash. at 120-21, 110 P. at 1024.

${ }^{93}$ See Working Papers, supra note 5, at 252.

${ }^{94}$ See note 24 supra. The Brown Commission's minority proposal was that evidence 
More recently, five United States Supreme Court Justices have stated in dictum that punishment of involuntary conduct may violate the constitutional ban on cruel and unusual punishment. In Powell v. Texas ${ }^{95} \mathrm{Mr}$. Justice White joined the four dissenters in suggesting that if a defendant acted under compulsion (in that case, compulsion from intoxication), his conviction would violate the eighth amendment. ${ }^{96}$ Although the Court was unwilling, and quite properly so, to freeze experimentation with insanity defense formulations by articulating a constitutional formula for involuntariness, ${ }^{97}$ a majority was willing to require at least some defense based on the impairment of free will.

It would be folly to state categorically that, assuming adoption of the lemon-squeezing interpretation, section 522 will be ruled unconstitutional. ${ }^{98}$ But one can predict that many courts will be less than overwhelmed by the Senate Judiciary Committee's scanty justification for so major a departure from common law tradition on the culpability issue. Given judicial reluctance to constitutionalize the insanity defense, ${ }^{99}$ the more probable fate of section 522 in the courts is that it will be construed in such a manner as to resolve indirectly the serious and difficult constitutional questions it provokes. It is to this subject that we now turn.

\section{ENLARgING MENS REA}

Motivated by constitutional concerns and the policy interests in not "depriv[ing] the criminal law of its chief paradigm of free

of mental disease or defect be admissible to negate any element of the crime, including the voluntariness requirement which the Commission included in its actus reus provisions. Working PAPERS, supra note 5, at 234.

95392 U.S. 514 (1968).

${ }^{96} \mathrm{Id}$. at 548-54 (White, J., concurring); id. at 565-70 (Fortas, J., dissenting).

${ }^{97}$ A generation ago the Court in Leland v. Oregon, 343 U.S. 790, 800-01 (1952), refused to hold that the "irresistible impulse" test of insanity is "implicit in the concept of order liberty." If Leland is still good law (and the relevant dicta in Powell do not criticize it), then not every involuntary action caused by mental illness is constitutionally protected from criminal prosecution.

${ }^{98}$ See note 97 supra.

${ }^{99}$ Consider, for example, the following testimony of Chief Judge David L. Bazelon, Jr.:

Justice Frankfurter told me privately that he intended to make every effort to avoid a Supreme Court ruling on the definition of the "insanity" defense. The matter was too fluid, too susceptible of change, too much oriented to the individual case for a Supreme Court pronouncement to do anything other than misdirect the development of the law in this area.

1975 Hearings, supra note 11, at 228-29. See Greenwood v. United States, 350 U.S. 366, 376 (1956) (Frankfurter, J.): "Certainly, denial of constitutional power of commitment to 
will,"100 courts may capitalize on two analytical footholds to circumvent the narrow lemon-squeezing interpretation of section 522: (1) the suggestion in some provisions of S. 1 of a concept of culpability broader than mere awareness of conduct, circumstances, and results, and (2) judicial experience with the defense of diminished capacity. Both approaches would enable a reviewing court to broaden the section 522 defense by broadening the concept of mens rea in sections 301 and 302 to reflect a larger, less objective concept of culpability. Both lead to revival of an insanity defense similar to existing formulations at the expense of muddying the attempt to articulate an objective view of mens $r e a$ in sections 301 and 302 .

The first approach begins with section 522 itself. If evidence of mental disease or defect is relevant only to establish the absence of a mens rea element, then section 522 would seem redundant given sections 301 and 302 and the mistake-of-fact-or-law defense in section 521.101 To avoid the redundancy, it has been argued, ${ }^{102}$ one might assume that section 522 has reference to aspects of culpability beyond those reflected in sections 301 and 302 , and that the term "mental disease or defect" adds substantively to mens rea. The argument is bolstered by the absence of any voluntariness requirement in the conduct sections of S. $1 .{ }^{103}$ A court might infer from this omission either that the draftsmen intentionally abolished involuntariness as a defense, a conclusion creating serious constitutional tensions, or that they meant to transfer considerations of voluntariness to the mens rea elements of sections 301 and $302 .{ }^{104}$ The latter view would allow the de-

Congress in dealing with a situation like this ought not to rest on dogmatic adherence to one view or another on controversial psychiatric issues."

${ }^{100} \mathrm{H}$. PACKer, supra note 1 , at 132.

101 S. 1, 94th Cong., Ist Sess. $\$ 521$ (1975) provides:

It is a defense to a prosecution under any federal statute that, as a result of ignorance or mistake concerning a matter of fact or law, the defendant lacked the state of mind required as an element of the offense charged. Except as otherwise provided, ignorance or mistake concerning a matter of fact or law does not otherwise constitute a defense.

1021975 Hearings, supra note 11, at 219 (statement of Chief Judge David L. Bazelon, Jr.).

${ }^{103}$ See note 24 supra.

${ }^{104}$ Section 501 gives the courts authority to infer defenses not specified in S. 1 but forbids expansion of named defenses beyond the limits of the statute. Although the specific language of $\S 522$ would prohibit evidence of mental disease or defect for any purpose other than to negate mens rea (e.g., to negate the conduct element in $\S 102)$, this language does not prevent a court from reading the mens rea provisions (\$\$ 301-02) more expansively. See generally A. Goldstein, supra note 1, at 207. 
fendant to raise the issue of his ability to control his conduct, ${ }^{105}$ quite apart from his ability correctly to perceive what he was doing, and to apply evidence of mental disease or defect, through section 522, to the resolution of that issue.

The principal flaw in this approach is the initial assumption of redundancy. If section 522 is redundant, so is the similarly worded section 521 on mistake of fact or law. Yet section 521 does not add substantively to mens rea. ${ }^{106}$ Furthermore, the draftsmen may have felt section 522 necessary to make explicit their intent to repeal the judicially created insanity defenses now operative in the federal system, ${ }^{107}$ just as section 521 clears up judicial differences over the role of mistake of fact or law. ${ }^{108}$ Nevertheless, if Congress intends to do no more than to lay down a rule of evidence for the proper scope and relevance of testimony concerning mental disease or defect in a criminal trial, that purpose could be more clearly achieved by adding a clause to sections 301 and $302 .{ }^{109}$ To set out such a rule separately, in a subchapter of the statute entitled "Defenses Based on Lack of Culpability"110 is to suggest that the insanity defense has a substance that the Committee's Staff Report disclaims.

105 Such a construction would also tend to expand current conceptions of the automatism or involuntariness defense which limit it to cases of somnabulism and occasional cases of psychomotor epilepsy. E.g., Fain v. Commonwealth, $78 \mathrm{Ky} .183$ (1879) (evidence of somnabulism should have been admitted); Bratty v. Attorney-General, [1963] A.C. 386 (H.L. 1961) 3 W.L.R. 965 (H.L.) ("involuntariness" does not include involuntariness due to disease of mind unless a disease within limits of M'Naghten or automatism (reflex, convulsive, or unconscious or somnabulistic action) is proven).

${ }^{106}$ JUdiciary Comm. StafF Report, supra note 7, at 94 . But see 1975 Hearings, supra note 11, at 228 (statement of Chief Judge David L. Bazelon, Jr.).

${ }^{107}$ Additionally, $\S 522$ codifies the holding of Davis v. United States, 160 U.S. 469 (1895) (nonconstitutional common law decision), placing the burden of persuasion beyond a reasonable doubt on the prosecution. Section 522 also purports to focus the jury's (and the expert witness') consideration of evidence of mental disease or defect on the issue of mens rea; arguably, current formulations leave the jury at large to do what they will with evidence of insanity.

For existing federal court formulations of the insanity defense, see note 135 infra.

${ }^{108}$ See generally W. LAFAve \& A. Scotr, Criminal Law 356-69 (1972); Judiciary

Comm. Staff Report, supra note 7, at 94-97.

${ }^{109}$ Chief Judge David L. Bazelon, Jr., has stated:

I would suggest the following additional explanation be added to clarify such an intent: "Evidence of a mental disease or defect shall be admissible for the purpose of demonstrating that a person was unaware of the factual circumstances of his conduct or of the existence of a risk, and for no other purposes." This additional language should be placed in $\S 301$ and $\S 522 \ldots$ should be eliminated.

1975 Hearings, supra note 11 , at 229.

110 The third defense in this subchapter, intoxication ( $\$ 523$ ), is likewise susceptible of two substantially different interpretations. On a narrow reading, it functions like 
Nor are certain other S. 1 defenses consistent with the limited concept of culpability suggested by the lemon-squeezing interpretation of section 522. The affirmative defense of duress in section 531, under the heading "Defenses Based on Lack of Volition," exculpates offenders "of reasonable firmness" who are aware of what they are doing but whose powers of control are impeded by the coercion of "another person." Provocation is a simple defense to murder for the "ordinary person,"111 having the effect of downgrading the offense to manslaughter. ${ }^{112}$ Reference to the reasonable or ordinary person in both defenses would presumably preclude their use by one suffering from mental disease or defect except to the extent that the provocation or duress would produce the same reaction in the "reasonable man." 13 And in any event, constitutional concerns may cause courts to balk at an interpretation that permits an offender to be exculpated for an overpowering of the will by human agency or "ordinary" fits of pique but not by mental disease or defect. ${ }^{114}$

Further inducement to allow the objective view of nzens rea in sections 301 and 302 to be "pried open" by section 522 comes from state court experience with the defense of diminished capacity. Since practically every American jurisdiction maintains a separate insanity defense along the lines of either M'Naghten or the American Law Institute formulation, ${ }^{115}$ the function of the

mistake of fact or law and the lemon-squeezing interpretation of $\$ 522$ to negate the mens rea element of "intent" or "knowledge." Section 523, however, precludes the use of the defense to negate a mens rea element of recklessness or negligence. As such, § 523 is a limitation of the general defense suggested by $\S \S 301-02$ and not a separate defense. On a broader reading, intoxication, like mental disease or defect, may suggest a notion of culpability broader than that reflected in the objective view of mens rea. Like $\S 522, \S 523$ can be seen as infusing aspects of the defendant's capacity for judgment and control of his actions into §§ 301-02. See People v. Hood, 1 Cal. 3d 444, 458, 462 P.2d 370, 379, 82 Cal. Rptr. 618, 627 (1969):

[A] drunk man is capable of forming an intent to do something simple, such as strike another, unless he is so drunk that he has reached the stage of unconsciousness. What he is not as capable as a sober man of doing is exercising judgment about the social consequences of his acts or controlling his impulses towards antisocial acts.

${ }^{111}$ S. 1, 94th Cong., 1st Sess. § 1601(b) (1975).

${ }^{112} I d . \S 1602(\mathrm{a})(2)$.

${ }^{113}$ This statement would not be true if a court were to read into the subjective language "in the position of the defendant" the fact of the defendant's mental disease or defect. See note 14 supra. See generally A. Goldstein, supra note 1, at 197-98.

${ }^{114}$ See notes 85-98 supra \& accompanying text.

115 Model Penal Code $\$ 401$ (1) (Proposed Official Draft, 1962): "A person is not responsible for criminal conduct if at the time of such conduct as a result of mental 
diminished capacity defense is to allow the jury to consider psychological evidence insufficient to exculpate totally for the purpose of downgrading the level of culpability attaching to the defendant's criminal conduct. By its very nature, the defense suggests a notion of culpability broader than mere awareness of conduct, circumstances, and results. Nevertheless, the defense is normally used to negate a mens rea element required by the definition of the offense. ${ }^{116}$ Hence, courts adopting the defense have had to broaden their mens rea definitions to encompass more than mere conscious awareness.

California provides the textbook illustrations. In People $v$. Gorshen, ${ }^{117}$ evidence of "uncontrollable compulsion" was deemed relevant to suggest the absence of malice aforethought, the mental element required for second degree murder, even though such evidence was excludable on the issue of the insanity defense since California had rejected the irresistible impulse test. ${ }^{118}$ In People v. Wolff, ${ }^{119}$ the first degree murder requirement of a willful, deliberate, and premeditated killing was interpreted to include consideration of the "extent to which this defendant could maturely and meaningfully reflect upon the gravity of his contemplated act." 120 The purpose of such inquiry was to assess "the quantum of his moral turpitude and depravity."121 And in People $v$. Conley ${ }^{122}$ the court ruled that a defendant could not be found to have acted with malice aforethought if he were "unable to comprehend his duty to govern his actions in accord with the duty imposed by law." 123

To be sure, the mens rea elements under review in the above cases are not precisely those set out in sections 301 and 302 of S. 1. But the process that the California courts underwent to adjust what had previously been a primarily objective concept of mens rea, rendering it more subjective to accommodate evidence of mental abnormality, is critical to evaluating the likely

\footnotetext{
disease or defect he lacks substantial capacity either to appreciate the criminality [wrongfulness] of his conduct or to conform his conduct to the requirements of the law." But see State v. Pike, 49 N.H. 399 (1870) ("product" test similar to Durham).

${ }^{116}$ Dix, supra note 91 , at $324-27$.

${ }^{117} 51$ Cal. 2d 716, 336 P.2d 492 (1959), noted in 12 Stan. L. Rev. 226 (1959).

${ }^{118}$ Id. at 727,336 P.2d at 498-99.

${ }^{119} 61$ Cal. 2d 795, 394 P.2d 959, 40 Cal. Rptr. 271 (1964).

${ }^{120} \mathrm{Id}$. at $821,394 \mathrm{P} .2 \mathrm{~d}$ at $975,40 \mathrm{Cal}$. Rptr. at 287 (emphasis in original).

${ }^{121}$ Id. at 822, 394 P.2d at 976, $40 \mathrm{Cal}$. Rptr. at 288.

12264 Cal. 2d 310, 411 P.2d 911, 49 Cal. Rptr. 815 (1966).

${ }^{123}$ Id. at 322,411 P.2d at 918,49 Cal. Rptr. at 822.
} 
fate of section 522. ${ }^{124}$ The primary advantage of such a process is that, unlike the all or nothing proposition of the separate insanity defense, it permits more refined judgments of an offender's culpability. The primary disadvantage is that to reach such refined judgments, some degree of chaos must be endured as courts struggle to rewrite mens rea to harmonize it with modern psychological theory. ${ }^{125}$ Along the way, expert witnesses and trial judges must suffer the indignity of petty intellectual dishonesties as testimony is bent to the demands of materiality and relevance. And, in the end, the process may turn out to be less effective than the separate insanity defense in bringing to the trier of fact all psychological evidence bearing on culpability. As Professor Dix has noted of the California experience: "Despite the effort the court has expended, it has gone no further than to develop the cognitive aspects of the state of mind requirements. ... It does not . . . provide a satisfactory vehicle for doctrinal analysis of more complex and sophisticated problems . ..."126

Thus, judicial construction could transform section 522 into a cross between M'Naghten and Durham-the former because of the emphasis on cognition in Sections 301 and $302,{ }^{127}$ the latter because the issue of mental illness negating a mental element so closely resembles the Durham issue of productivity. ${ }^{128}$ Such a course will surely thwart the draftsmen's hopes of removing psychiatrists from the courtroom ${ }^{129}$ and is unlikely to improve communication among judge, expert witness, and jury. Nor does it begin to resolve the principal problem plaguing the insanity defense today, that of "expert dominance."130 By insisting on a factual finding of mental disease or defect, section

${ }^{124}$ For another example of this process, see Rhodes v. United States, 282 F.2d 59 (4th Cir. 1960) (mens rea element of knowledge interpreted to include "capacity to know," on which psychiatric evidence deemed relevant).

${ }^{125}$ For evidence of this chaos and the highly subjective decisions that may result, compare the majority and dissenting opinions in People v. Goedecke, $65 \mathrm{Cal}$. 2d 850, 423 P.2d 777, 56 Cal. Rptr. 625 (1967).

${ }^{126}$ Dix, supra note 91, at 331. For a discussion of the California experience in modifying mens rea definitions, see id. 328-32.

${ }^{127}$ The California experience emphasizing cognitive aspects of mental capacity must be evaluated in the context of a parallel full insanity defense derived from M'Naghten. The absence of a separate $S$. 1 insanity defense could conceivably lead the federal courts to view mens rea even more subjectively than the California courts.

${ }^{128}$ See note 12 supra.

${ }^{129}$ See notes 47-53 supra \& accompanying text.

${ }^{130} 1974$ Hearings, supra note 11, at 224 (statement of Chief Judge David L. Bazelon, Jr.). 
522 perpetuates our modern tradition of asking medical experts to resolve for us the moral and legal issue of criminal responsibility. ${ }^{131}$

\section{Alternatives}

In urging the abolition of a separate insanity defense, Dean Morris observed, "It too often is overlooked that one group's exculpation from criminal responsibility confirms the inculpation of other groups."132 That simple perception provides as well the principal justification for retention of the defense. For it is through the on-going, case-by-case process of exculpating the non-responsible that society evolves its concepts of individual autonomy and accountability. As long as we retain our commitment to the political ideal that an individual is able in some degree to control his own destiny, we shall resist efforts to eliminate our principal mechanism for testing that capacity in our criminal law. ${ }^{133}$ If we abolish in large measure the defense of blamelessness, we detract from our ability to impose blame. The number of offenders so exculpated is likely to remain small; they are the exception we use to prove the rule of personal accountability. Symbolically, their significance outstrips the social gains to be realized by submitting them to our largely ineffective correctional process.

What, then, should Congress do about the insanity defense? There is little to be gained by adopting the recommendation of the Brown Commission. ${ }^{134}$ Because virtually every circuit has adopted a close facsimile of that test ${ }^{135}$ and because it fails to

\footnotetext{
${ }^{131}$ See id.; Ennis \& Litwack, Psychiatry and the Presumption of Expertise: Flipping Coins in the Courtroom, 62 CALIF. L. REv. 693 (1974); note 53 supra.

132 Morris, supra note 1 , at 520 .

${ }^{133}$ See A. GoldsteIn, supra note 1 , at 223-26; 1973 Hearings, supra note 12 , at 6378-79 (statement of Prof. Abraham S. Goldstein).

${ }^{134}$ Report of the National Comm'n on Reform of Federal Criminal Laws, Hearings Before the Subcomm. on Criminal Laws and Procedures of the Senate Comm. on the Judiciary, 92d Cong., 1st Sess., pt. 1, at 194 (1971):
}

$\S 503$. Mental Disease or Defect

A person is not responsible for criminal conduct if at the time of such conduct as a resut of mental disease or defect he lacks substantial capacity to appreciate the criminality of his conduct or to conform his conduct to the requirements of law. "Mental disease or defect" does not include an abnormality manifested only by repeated criminal or otherwise antisocial conduct. Lack of criminal responsibility under this section is a defense.

${ }^{135}$ See United States v. Brawner, 471 F.2d 969, 979-85 (D.C. Cir. 1972); Wade v. United States, 426 F.2d 64, $71-73$ (9th Cir. 1970); Blake v. United States, 407 F.2d 908, 915-16 (5th Cir. 1969); United States v. Smith, 404 F.2d 720, 727 (6th Cir. 1968); United 
answer the principal criticisms of the insanity defense respecting expert dominance and the illogical strictures of the medical model, legislation would achieve no more than to curtail what limited experimentation exists today. Indeed, one may doubt any special competence of a legislative body, dealing with the issue on an abstract level, to formulate a "test" of criminal responsibility. The better forum for evolving our notions of personal accountability and measuring them against our developing knowledge of human behavior may be, as Judge Bazelon has argued, individual cases. ${ }^{136}$ For it is the individual case which provides us with bits and pieces of the knowledge we now lack. And it is the jury, subject to judicial guidance, which, when face to face with the power to decide the fate of the accused before them, may be society's most efficacious representative in drawing the moral line. The first option, then, is for Congress to stay its hand, to provide procedures for raising a defense of lack of criminal responsibility, ${ }^{137}$ but to leave the substantive "test" to the common law.

A second option would be to clear away the obstacles of expert dominance and the medical model which now encumber full jury consideration of the responsibility issue. Judge Bazelon's suggested jury instruction represents one such formula: "[A] defendant is not responsible if at the time of his unlawful conduct his mental or emotional processes or behavior controls were impaired to such an extent that he cannot justly be held responsible for his act."138 Like the option of doing nothing, this option leaves the law of criminal responsibility free to develop with judicial experience. ${ }^{139}$ In addition, it enhances that development by re-

States v. Chandler, 393 F.2d 920, 926-27 (4th Cir. 1968); United States v. Shapiro, 383 F.2d 680, 684-87 (7th Cir. 1967); Pope v. United States, 372 F.2d 710, 735-36 (8th Cir. 1967), vacated and remanded on other grounds, 392 U.S. 651 (1968); United States v. Freeman, 357 F.2d 606, 622-24 (2d Cir. 1966); Wion v. United States, 325 F.2d 420, 430 (10th Cir.), cert. denied, 377 U.S. 946 (1963); United States v. Currens, 290 F.2d 751, 774 \& n.32 (3d Cir. 1961).

1361975 Hearings, supra note 11, at 226-28 (statement of Chief Judge David L. Bazelon, Jr.).

${ }_{137}$ See, e.g., S. 1, 94th Cong., 1st Sess. §§ 3612(a), 3617 (1975).

${ }^{138}$ United States v. Brawner, 471 F.2d 969, 1032 (D.C. Cir. 1972) (Bazelon, C.J., concurring and dissenting).

${ }^{139}$ Appellate supervision of the "justly responsible" test would be altered to the extent that appellate courts would no longer be able to base their rulings upon formal definitions of "mental disease or defect." Additionally, the test suggests greater deference to a properly instructed jury's determination of community standards of blameworthiness. Whether such a test renders the definition more lawless depends on one's perception of the operation of existing insanity defense formulations. If the element of "mental 
moving the distraction of determining whether a defendant's condition may properly be termed "mental disease or defect" and concomitantly reducing the jury's dependence on expert witnesses. It tells the jury that mental processes are at issue without requiring a particular medical diagnosis. Finally, it focuses jury attention on what must be the central issue: the balance to be struck between moral blameworthiness and the concerns of social order. ${ }^{140}$

Neither option addresses the important practical issue of what is to be done with an offender acquitted for nonresponsibility and perceived as mentally ill and a continuing threat to others. But that issue should be analytically distinct from the issue of responsibility irrespective of the legal test employed. ${ }^{141}$ Preventive confinement addresses future conduct: Past conduct is relevant only as a factor for prediction. Whether or not a jury found the actor criminally responsible for such past conduct is otherwise irrelevant to a determination of preventive confinement. ${ }^{142}$ Indeed, one hidden benefit of the second option, the "justly responsible" test, ${ }^{143}$ may be that it will force us to confront the real issues in preventive confinement which now lie masked behind the "special verdict" of "not guilty by reason of insanity." 144

disease or defect" in current formulations is simply an excuse for the expert witness to inject into the record personal judgments on the ultimate issue of responsibility, see note 131 supra, then current practice may be as insulated from appellate scrutiny as the "justly responsible" approach.

1401975 Hearings, supra note 11, at 226 (statement of Chief Judge David L. Bazelon, Jr.). This standard has also been suggested as the most appropriate way to deal with psychological evidence that might warrant a finding of diminished capacity but not total exculpation. See Dix, supra note 91, at 333-34.

${ }^{141}$ See note 56 supra.

${ }^{142}$ Lack of capacity to control given conduct in one set of circumstances does not necessarily imply lack of capacity to control other conduct in other circumstances. For one thing, the underlying mental disability may have undergone spontaneous remission. For another, the disordered thinking may be limited to one particular deed, as when one spouse kills another believing the victim to be the devil.

${ }^{143}$ See text accompanying notes $138-40$ supra.

${ }^{144}$ Such is the terminology employed in S. 1, 94th Cong., 1st Sess. § 3612(b) (1975). 